\title{
Algılanan Nepotizmin İşgören Performansı Üzerindeki Etkisinde Örgütsel Yalnızlığın Aracılık Rolü: Kamu ve Özel Sektör Karşılaştırması ${ }^{1}$
}

\section{Mediating Role of Organizational Loneliness in the Effect of Perceived Nepotism on Employee Performance: Comparison of Public and Private Sector}

Özlem İBİş², Meryem Derya YEŞiLTAŞ³

\begin{abstract}
$\overline{\mathbf{O z}}$
Amaç: Araştırmanın amacı, nepotizmin örgütsel yalnızlık ve işgören performansının üzerindeki etkilerini araştırmaktır. Ayrıca nepotizmin iş gören performansı üzerindeki etkisinde örgütsel yalnızlığın aracı (mediator) rolünü incelemektir.

Tasarım/Yöntem: Hatay ilinde kolayda örneklem ve kartopu örnekleme yöntemleri kullanılarak 407 (212 özel sektör ve 195 kamu çalışanı) geçerli anket ile veri toplanmıştır. Özel sektör ve kamu çalısanları iki farklı örneklem olarak değerlendirilmiștir. Bu çalı̧̧mada, "güvenirlik analizleri", "keşifsel faktör analizleri", "bağımsız örneklem t- testi", "Pearson korelasyon analizi", "basit doğrusal regresyon analizi", "hiyerarşik regresyon analizi" ve "Sobel testi" kullanılmıştır.

Bulgular: Analiz bulgular1; her iki örneklemde de nepotizmin örgütsel yalnızlığı etkilediğini; özel sektör çalışanlarında nepotizmin işgören performansı üzerindeki etkisinde örgütsel yalnızlığın aracı rolü olduğunu; kamu çalışanlarında ise nepotizmin ne örgütse yalnızlığı ne de işgören performansını etkilemediği belirlenmiştir.
\end{abstract}

Sınırılıklar: $\mathrm{Bu}$ çalışma, zaman ve maliyet kısıtları nedeniyle Hatay ilindeki katılımcılarla gerçekleştirilmiştir. Veri toplama sürecinin Covid-19 Pandemisine denk gelmiş olması da örnekleme ulaşmak adına bir kısıt olușturmustur.

Özgünlük/Değer: Araştırma, nepotizmin daha önce test edilmediği örgütsel yalnızlık kavramı ile ilişkisinin incelenmesi ile kamu ve özel sektörün karşılaştırılmasının değişkenlerin anlaşılmasına ve yönetilmesine katkı sağlayabilecek sonuçlara ulaşılması bakımından önem taşımaktadır.

Anahtar Kelimeler: Nepotizm, Örgütsel Yalnızlık, İşgören Performansi, Aracilık

\begin{abstract}
Purpose: The purpose of this study is to examine the effects of nepotism on organizational loneliness and employee performance. It is also to examine the role of organizational loneliness as a mediator in the impact of nepotism on employee performance.

Design/Methodology: The data was collected from 407 valid surveys (212 private sector employees and 195 public employees) by using the convenience sampling and snowball sampling methods in Hatay. Private sector and public employees were evaluated as two different samples. In this study, "reliability analysis", "exploratory factor analysis", "Independent sample t-test", "Pearson correlation analysis", "simple linear regression analysis", "hierarchical regression analysis" and "Sobel Tests" were used.

Findings: The results of the analysis show that nepotism has significant positive effect on organizational loneliness among both samples. Organizational loneliness has significant mediating role on the relationship between nepotism and employee performance among private sector employees. Nepotism does not affect neither organizational loneliness nor employee performance among public employees.

Limitations: This study was carried out with the participants in Hatay province due to time and cost constraints. The fact that the data collection process coincided with the Covid-19 Pandemic also created a limitation to reach the sample.

Originality/Value: The research is important in terms of examining the relationship between nepotism with the concept of organizational loneliness, which has not been tested before, and also reaching results that can contribute to understanding and managing variables by comparison of public and private sector.

Keywords: Nepotism, Organizational Loneliness, Employee Performance, Mediator
\end{abstract}

\footnotetext{
${ }^{1}$ Bu makale, Özlem İBİŞ’in Osmaniye Korkut Ata Üniversitesi, SBE, İşletme Ana Bilim Dalı, Yönetim ve Organizasyon Bilim Dalı Tezli Yüksek Lisans Programında Dr. Öğr. Üyesi Meryem Derya YEŞİLTAŞ danışmanlığında hazırladığı yüksek lisans tezinin bir kısmından oluşturulmuştur.

${ }^{2}$ Yüksek Lisans Öğrencisi, Osmaniye Korkut Ata Üniversitesi, SBE, İşletme Ana Bilim Dalı, Yönetim ve Organizasyon Bilim Dal1, ozlemibis85@gmail.com, ORCID: 0000-0003-4366-3421

${ }^{3}$ Dr. Öğr. Üyesi, Osmaniye Korkut Ata Üniversitesi, İIBB, İşletme Bölümü, deryayesiltas@ osmaniye.edu.tr, ORCID: 00000001-5067-4538
} 


\section{GİRIŞ}

Örgütlerde farklı pozisyonlara en uygun çalışanların seçimi, örgütün başarısı ve hedeflerine ulaşması açısından son derece önemlidir (Çetinkaya \& Sanioğlu Tanış, 2017). Örgütlerde personel seçimi ve görevlendirme önemli bir konu olmasına rağmen işe alımlarda çalışanın yetenek, bilgi ve kabiliyetlerinin göz ardı edilerek akraba, eş-dost ve hemşerilik gibi ölçütler baz alınarak seçim yapılabilmektedir. Halk arasında "torpil" olarak da adlandırılan bu kavram kayırmacilık olarak isimlendirilmektedir (Büte, 2011a: 385). Kayırmacı uygulamaların geçmişi çok eskiye dayanmakla beraber, etkisi günümüze kadar artarak devam etmektedir. Kayırmacılık, geniş kapsamlı bir kavram olarak altında birçok türü barındırmaktadır (Asunakutlu \& Avc1, 2010). Nepotizm, kayırmacılığın bir alt türü olarak, kan bağına dayalı kayırmacılığı ifade etmektedir (Riggio \& Saggi, 2015).

Nepotizm, bir örgütte patronun veya yöneticinin aile üyelerine istihdam bağlamında ayrıcalıklı davranmasını, liyakat ve yeteneklerden ziyade akrabalık bağlarına dayalı işe alımları (Firfiray vd., 2018), terfileri ve işlem kolaylıklarını (Çalık, 2018) ifade etmektedir. İnsanlar için aile ve sonra da akrabalar vazgeçilmez varlıkların başında gelmektedir. Nepotizm, kişilerde doğuştan var olan akrabalık bağının kayırmacı yönünün dışa yansımasıdır (Avc1, 2017). Nepotizme, hem gündelik hayatta hem de iş ortamında yani toplumsal sistemin hemen her alanında rastlanmaktadır (Kaba \& Aktaş, 2018). Bu duruma hem kamu hem sivil toplum kuruluşları hem de özel sektörde rastlanmaktadır (Bayhan, 2002). Özel sektör bazında özellikle aile işletmelerinde, personel alımı sırasında bilgi, beceri ve yetenek gibi ölçütler dikkate alınmaksızın, aile bireylerine öncelik tanınması ve kilit pozisyonlara bu kişilerin getirilmesiyle, işletme kurallarının önüne geçilmektedir. Bu durum kurumsallaşamamış olumsuz bir yönetim yaklaşımını göstermektedir (Barbaros, 2015).

Nepotizmin yönetim ve organizasyon alanında incelenmesi yakın tarihe dayanıyor olsa da uygulama yönünden tarihinin orta çağa kadar dayandığı bilinmektedir (Asunakutlu \& Avc1, 2010). Dünyada ve ülkemizde nepotizmin etkilerinin tam olarak anlaşllabilmesi ve gerek örgütler gerekse çalışanlar üzerindeki olası olumsuz etkilerinin belirlenerek önlemler alınabilmesi için bu alanda daha fazla çalışmanın yapılmasına ihtiyaç duyulmaktadır (Özkan, 2019). Nepotizmin çalışan bazında olumsuz etkileri genel olarak; motivasyon, güven, bağl1lık, tatmin, sadakat ve performansa bağl1 olumsuzluklardır (Kaba \& Aktaş, 2018).

Türkiye'deki çalışmalar incelendiğinde, nepotizmin iş tatmini, iş stresi (Büte, 2011b), örgütsel adalet (Karacaoğlu \& Yörük, 2012), işten ayrılma niyeti (Sipahi \& Kartal, 2018), örgütsel bağl1l1k (Karahan \& Yılmaz, 2014), güven (Keleş vd., 2011), örgütsel sinizm (Gül, 2016) gibi kavramlar ile birlikte ele alındığı görülmektedir. Bunlar arasında nepotizmin ile işgören performansı arasındaki ilişkiyi inceleyen çalışma bulunmaktadır (Kaba \& Aktaş, 2018). Ancak örgütsel yalnızlık kavramı ile işgören performansı ve nepotizm kavramlarının birlikte incelendiği çalışmaya rastlanmamıştır. Avcı (2017), nepotizm ve yalnızlık kavramlarının ilişkili olabileceğini belirtmiş, ancak gerek uluslararası gerekse Türkiye'deki literatür incelemesi sonucunda, bu ilişkiyi test eden bir çalışmaya rastlanmamıştır. $\mathrm{Bu}$ durum araştırmanın hareket noktasını oluşturmaktadır. Araştırmanın amacı, algılanan nepotizm ile örgütsel yalnızlık kavramı arasındaki ilişkinin ortaya konulması, algılanan nepotizmin örgütsel yalnızlık ve işgören performansı üzerindeki etkilerinin ve örgütsel yalnızlı̆̆ın nepotizm ile iş gören performansı arasındaki rolünün belirlenmesidir. Araştırma, daha önce test edilmediği bir kavram ile ilişkisini inceleyerek nepotizm ile ilgili yeni bilgiler ortaya koyması bakımından önem taşımaktadır. Ayrıca, nepotizmin ele alındığı mevcut çalışmalar incelendiğinde araştırma alanının genellikle aile işletmeleri olduğu görülmektedir (Büte, 2011b; Karacaoğlu \& Yörük, 2012; Özkan \& Erdem, 2011; Asunakutlu \& Avc1, 2010; İyiişleroğlu, 2006). Bu nedenle, araştırma değişkenler arasındaki ilişkilerin kamu çalışanları ve özel sektör çalışanları açısından ayrı ayrı incelenmesi ve karşılaştırılması bakımından da önem taşımaktadır. Nepotizm, örgütsel yalnızlık ve işgören performansı arasındaki ilişkilerin incelenmesi, kamu ve özel sektör çalışanları arasında karşılaştırmalar yapılması bakımından, bu çalışma ile hem uluslararası literatüre hem de Türkiye'deki literatüre katkı sağlaması; yöneticilere ve çalışanlara faydalı bilgiler sunulması hedeflenmektedir.

\section{KURAMSAL ÇERÇEVE VE HIPOTEZLERIN OLUŞTURULMASI}

Örgütsel yalnızlık, kişinin özel hayatındaki yalnızlık algısından farklı olarak iş ortamında karşılaşmış olduğu yalnızlık algısıdır. Kişinin, iş ortamında ait olduğu çevrenin onu görmezden 
gelerek yalnızlaştırması şeklinde de yorumlanabilmektedir (Wright vd., 2006). Örgütsel yalnızlığın boyutlarından biri olan sosyal yalnızlık boyutu, bireyin kendisini işyerinde sosyal ağlardan kopuk hissederek bu anı dışında kalmasını ifade etmektedir. Bu durumda kişi, aidiyet duygusunu yitirerek işiyle ilgili duygu ve düşüncelerini paylaşmak istememekte ve kendilerini var olan arkadaş grubundan soyutlayabilmektedir (Kayaalp, 2019). Nepotizm, ekonomistlerin bir kişinin refah düzeyini düşürmeden bir başkasının refah düzeyinin yükseltilmesinin imkânsız olduğuna dayanan "pareto optimumu" kavramıyla da benzerlik göstermektedir. Nepotizmin de bu kuramda olduğu gibi, bir tarafa yarar sağlarken diğer tarafı zarara uğratması mümkündür (Riggio \& Saggi, 2015: 19). Nepotizm çalışanlarda, örgüte karşı adalet algısının zayıflamasına ve güven eksikliğine sebep olmaktadır. Akrabalık ilişkisi, aile bağı gibi nedenlerle gruplaşmanın var olduğu örgütlerde, akraba olmayan diğer çalışanlara karşı psikolojik baskılar oluşabilmektedir. Böyle bir ortamda kendini yalnız ve huzursuz hisseden çalışanlarda tükenmişlik ve işe karşı tatminsizlik gibi sorunlar ortaya çıkabilmektedir (Avcı, 2017). Örgütsel yaşamda farklı meslek gruplarının yalnızlık düzeylerinin de farklılık gösterebileceği öne sürülmektedir. Buna göre yöneticilerin hem örgüt içerisinde hem de iş dışı yolculuklarında yalnız olduklarını ve bunu önlemek için rekabetin olmadığı samimi dostluk arayışı içerisinde oldukları belirtilmektedir (Kayaalp, 2019). Böyle bir durumda yöneticiler, yalnız kalmamak ve samimi bir iş ortamı oluşturmak adına nepotizme başvurabilirler. Bu da yalnızlığı nepotizmin hem nedeni hem de sonucu haline getirebilmektedir. Yani kurumda nepotizmin çalışanlarda yalnızlığa yol açtığı varsayılırken, başka bir taraftan da yalnız kalmamak adına nepotizme başvurulmuş olunabilir. Yapılan literatür taraması sonucunda yerli ve yabancı kaynaklarda, örgütsel yalnızlık ve nepotizmin birlikte ele alındığı bir çalışmaya rastlanmamıştır. Ancak nepotizmin neden ve sonuçlarının, örgütsel yalnızlığa zemin hazırlayabileceği varsayılmaktadır (Avc1, 2017). İncelenen çalışmalarda, nepotizmin varlığının örgütteki akraba olmayan diğer çalışanlar üzerinde olumsuz etkilerinin, örgütsel yalnızlığa yol açabileceği düşünülmektedir (Savaş, 2015).

Nepotizm örgüt içerisinde çalışanlar temel alındığında, iki boyuttan oluşmaktadır. İlki nepotizm uygulanması ile kayrılan çalışanlar, ikincisi ise bunun dışında kalan diğer çalışanlardır. Nepotizmin kayrılan çalışanlar açısından, hem olumlu hem olumsuz etkileri mevcutken, kayrılmayan çalışanlar için genellikle olumsuz etkilerinden söz edilmektedir. Nepotizm, kayrılan çalışanlar üzerinde bir minnet duygusu oluşturarak performansın artmasına neden olabilmektedir (Üstük, 2018). Nepotizm, aile işletmeleri yönünden ele alınacak olursa, çalışanların aile bireylerinden oluşması, örgüt içerisinde işlerin daha istekli ve daha içten yapılmasına neden olarak verimliliği artırmaktadır. Dolayısıyla nepotizmin aile işletmeleri üzerinde bireysel performansı arttırdığı söylenebilmektedir (İyiişleroğlu, 2006). Bunun aksine Nepotizmin yoğun yaşandığı örgütlerde, akraba olmayan diğer çalışanlar üzerinde ise nepotizmin etkisi negatif yönlü olabilmektedir. Örgütte aile dışında olan çalışanlara güvenilmemesi, önemli görevlerin aile bireylerine verilmesi, adaletsiz dağıtımlar gibi olumsuz uygulamalar aileden olmayan çalş̧anlar üzerinde güven duygusunun azalmasına yol açabilmektedir. $\mathrm{Bu}$ durum çalışanın aidiyet duygusunun azalmasına ve performansının düşmesine neden olabilmektedir (Polat, 2012). Nepotizm, kayrılmayan diğer çalışanlar üzerinde moral düzeyini düşürmekte bunun sonucunda ise çalışan performansı olumsuz etkilenmektedir (Abdalla vd., 1998; Vateva, 2009; Barbaros, 2015). Nepotizmin var olduğu örgütlerde kayırılmayan diğer çalışanlar genellikle terfi edebilmek için, bireysel performanslarını artırmak yerine, örgütteki üst düzey yönetim ve onun akrabası olan çalışanlarla yakınlık kurmaya çalışmaktadırlar (Araslı \& Tümer, 2008).

Örgütsel yalnızlığın işgören performansını olumsuz yönde etkilemesi olasıdır. İşyerinde kendini yalnız hisseden çalışan, diğer çalışanlarla daha az iletişim kurmakta ve bu durum çalışanlar arasında olması gereken bilgi alışverişini olumsuz yönde etkilemektedir. Kritik öneme sahip bir bilginin paylaşılmasında yaşanan sorun sonucunda, işgören performansı düşebilmektedir (Demirbaş \& Haşit, 2016). İşyerinde yalnızlık duygusu, çalışanın örgüt hedefleri ve kişisel hedefleri arasındaki dengeyi sağlamakta güçlük çekmesine neden olabilmektedir. $\mathrm{Bu}$ durum, çalışanın performansını yeterince gösterememesine ve başarısızlık duygusuna kapılmasına yol açmaktadır. Yalnızlık, güvensizliğe, verimsizliğe, konsantrasyon eksikliğine ve düşük performansa sebep olabilmektedir (Bakioğlu \& Korkmaz, 2014). 
Araştırmalar sonucunda elde edilen bilgi ve bulgulardan hareketle, araştırmanın modeli (Şekil1) ve hipotezleri aşağıdaki gibi geliştirilmiştir.

\section{Şekil 1: Araştırma Modeli}

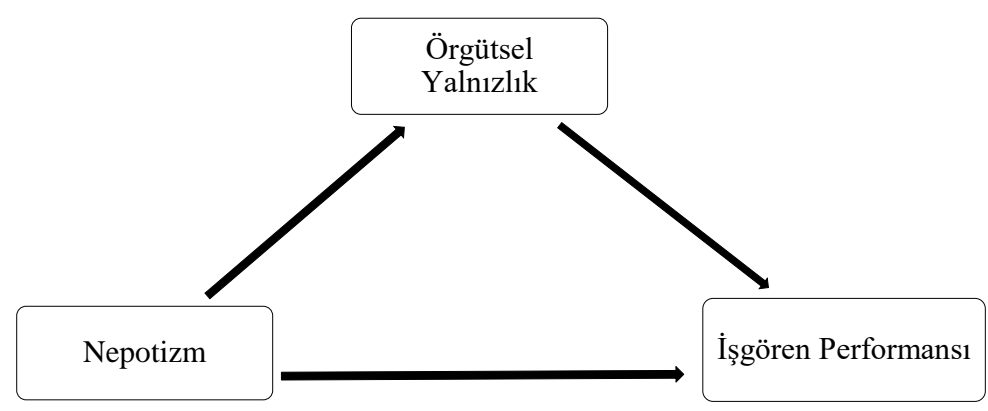

\section{Araştırmanın Hipotezleri}

$\mathrm{H}_{1}$ : Nepotizm, örgütsel yalnızlık ve işgören performansı arasında anlamlı bir ilişki vardır.

$\mathrm{H}_{1 \mathrm{a}}$ : Özel sektör çalışanlarının nepotizm, örgütsel yalnızlık ve işgören performansı arasında anlamlı bir ilişki vardır.

$\mathrm{H}_{1 b}$ : Kamu çalışanlarının nepotizm, örgütsel yalnızlık ve işgören performansı arasında anlamlı bir ilişki vardır.

$\mathrm{H}_{2}$ : Nepotizmin örgütsel yalnızlık üzerinde anlamlı bir etkisi vardır. etkisi vardır.

$\mathrm{H}_{2 \mathrm{a}}$ : Özel sektör çalışanlarının nepotizm algılarının örgütsel yalnızlık üzerinde anlamlı bir vardir.

$\mathrm{H}_{2 \mathrm{~b}}$ : Kamu çalışanlarının nepotizm algılarının örgütsel yalnızlık üzerinde anlamlı bir etkisi

$\mathrm{H}_{3}$ : Nepotizmin işgören performansı üzerinde anlamlı bir etkisi vardır. etkisi vardır.

$\mathrm{H}_{3 \mathrm{a}}$ : Özel sektör çalışanlarının nepotizm algılarının işgören performansı üzerinde anlamlı bir vardir.

$\mathrm{H}_{3 \mathrm{~b}}$ : Kamu çalışanlarının nepotizm algılarının işgören performansı üzerinde anlamlı bir etkisi

$\mathrm{H}_{4}$ : Örgütsel yalnızlığın işgören performansı üzerinde anlamlı bir etkisi vardır.

$\mathrm{H}_{4 \mathrm{a}}$ : Özel sektör çalışanlarının örgütsel yalnızlık algılarının işgören performansı üzerinde anlamlı bir etkisi vardır. bir etkisi vardır.

$\mathrm{H}_{4 b}$ : Kamu çalışanlarının örgütsel yalnızlık algılarının işgören performansı üzerinde anlamlı vardir.

$\mathrm{H}_{5}$ : Nepotizmin işgören performansı üzerindeki etkisinde örgütsel yalnızlığın aracılık rolü

$\mathrm{H}_{5 \mathrm{a}}$ : Özel sektör çalışanlarının algıladıkları nepotizmin işgören performansı üzerindeki etkisinde örgütsel yalnızlığın aracılık rolü vardır.

$\mathrm{H}_{5 b}$ : Kamu çalışanlarının algıladıkları nepotizmin işgören performansı üzerindeki etkisinde örgütsel yalnızlığın aracılık rolü vardır. 


\section{YÖNTEM}

\subsection{Evren ve Örneklem}

$\mathrm{Bu}$ çalışmanın amacı, çalışanların iş ortamında algıladıkları nepotizmin örgütsel yalnızlık ve işgören performansı üzerindeki etkilerinin yanısıra örgütsel yalnızlığın algılanan nepotizm ile işgören performansı arasındaki rolünün incelenmesidir. Araştırmanın yapılabilmesi için Osmaniye Korkut Ata Üniversitesi Bilimsel Araştırma ve Yayın Etiği Kurulu'ndan Etik Onay (Evrak Tarih ve Sayısı: 09/03/2020-7322) alınmıştır. Araştırma kapsamında Hatay ili genelinde 212 özel sektör ve 195 kamu çalışanı olmak üzere toplamda 407 katılımcıdan anket tekniği kullanılarak veri toplanmıştır. Özel sektör ve kamu çalışanları iki farklı örneklem olarak değerlendirilmiştir. Covid-19 pandemisinin ülkemizde görülmeye başlanması ile veri toplama sürecinin başlaması tarihlerinin denk gelmesi sebebiyle sürecin sağlıklı yürütülebilmesi için örneklem seçiminde "Kolayda Örnekleme" ve "Kartopu Örnekleme" yöntemleri birlikte kullanılmıştır. Ulaşılan katılımcılardan en az bir kişiye anketi ulaştırmaları istenmiş ve bu yolla yeni katılımcılara ulaşılmıştır. Mart-Nisan 2020 tarihleri arasında veriler toplanmıştır, veri toplama sürecinin Covid-19 pandemisine denk gelmesi sebebiyle katılımci sayısı sınırlı kalmıştır. Toplam 500 anket kamu ve özel sektör çalışanlarına dağıtılmış, 432 anket formunda geri dönüşs sağlanmıştır. Geri dönen anketlerin 25 tanesi eksik ve/veya yanlış doldurulmuş olması sebebiyle analize dâhil edilmemiştir. Geriye kalan 407 anket formu üzerinden analizler gerçekleştirilmiştir. Ankete katılanların 212'sini özel sektör çalışanları, 195'ini kamu çalışanları oluşturmaktadır. Anket geri dönüş oranı \%81,4'tür. Araştırmaya katılan 407 çalışanın bazı demografik özelliklerine ilişkin bilgiler Tablo 1'de yer almaktadır.

Tablo 1: Katılımcıların Demografik Özelliklerine Göre Dağılımları (Kamu ve Özel Sektör)

\begin{tabular}{|c|c|c|c|c|c|}
\hline \multicolumn{6}{|c|}{ Demografik Bulgular } \\
\hline $\begin{array}{l}\text { Demografik Özellikler } \\
\text { (Özel Sektör) }\end{array}$ & $\begin{array}{l}\text { Frekans } \\
\text { (n) }\end{array}$ & $\begin{array}{c}\text { Yüzde } \\
(\%)\end{array}$ & $\begin{array}{l}\text { Demografik Özellikler } \\
\text { (Kamu Sektörü) }\end{array}$ & $\begin{array}{l}\text { Frekans } \\
\text { (n) }\end{array}$ & $\begin{array}{c}\text { Yüzde } \\
(\%)\end{array}$ \\
\hline CINSIYYET & & & CINSIYET & & \\
\hline$\overline{\text { Kadın }}$ & 73 & 34,4 & $\overline{\text { Kadın }}$ & 64 & 32,8 \\
\hline Erkek & 139 & 65,6 & Erkek & 131 & 67,2 \\
\hline YAȘ & & & YAS & & \\
\hline 18 ve alt1 & 3 & 1,4 & 18 ve alt1 & 1 &, 5 \\
\hline $19-20$ & 15 & 7,1 & $19-20$ & 3 & 1,5 \\
\hline $21-25$ & 37 & 17,5 & $21-25$ & 18 & 9,2 \\
\hline $26-30$ & 44 & 20,8 & $26-30$ & 54 & 27,7 \\
\hline $31-35$ & 39 & 18,4 & $31-35$ & 39 & 20,0 \\
\hline $36-40$ & 33 & 15,6 & $36-40$ & 29 & 14,9 \\
\hline $41-45$ & 20 & 9,4 & $41-45$ & 23 & 11,8 \\
\hline $46-50$ & 7 & 3,3 & $46-50$ & 19 & 9,7 \\
\hline 51 ve üzeri & 14 & 6,6 & 51 ve üzeri & 9 & 4,6 \\
\hline EĞİTIM DURUMU & & & EĞİTIMM DURUMU & & \\
\hline İlkokul & 26 & 12,3 & İlkokul & 6 & 3,1 \\
\hline Ortaokul & 37 & 17,5 & Ortaokul & 11 & 5,6 \\
\hline Lise & 93 & 43,9 & Lise & 43 & 22,1 \\
\hline Ön Lisans & 30 & 14,2 & Ön Lisans & 39 & 20,0 \\
\hline Lisans & 22 & 10,4 & Lisans & 74 & 37,9 \\
\hline Yüksek Lisans & 2 & 9 & Yüksek Lisans & 22 & 11,3 \\
\hline Doktora & 2 & 9 & Doktora & 0 & 00,0 \\
\hline İS YERİNDEKİ GÖREV SÜRESİ & & & İS YERİNDEKİ GÖREV SÜRESİ & & \\
\hline 1 Yildan Az & 35 & 16,5 & 1 Yildan Az & 23 & 11,8 \\
\hline 1-3 Yll & 61 & 28,8 & 1-3 Yıl & 59 & 30,3 \\
\hline 4-6 Y1l & 54 & 25,5 & 4-6 Yil & 50 & 25,6 \\
\hline 7-9 Yil & 17 & 8,0 & 7-9 Y11 & 26 & 13,3 \\
\hline 10 Y1l ve Üzeri & 45 & 21,2 & 10 Y1l ve Üzeri & 37 & 19,0 \\
\hline
\end{tabular}

Tablo 1'de görüleceği üzere, araştırmaya katılan özel sektör çalışanlarının \%34,4'ünü (73) kadın çalışanlar, \%65,6'sını (139) erkek çalışanlar oluşturmaktadır. Kamu çalışanlarının ise \%32,8'ini (64) kadın çalışanlar, \%67,2 (131) erkek çalışanlar oluşturmaktadır. Özel sektör çalışanlarının çoğunluğunu \%20,8 ile 26-30 yaş aralığına sahip 44 çalışan oluşturmaktadır. Kamu sektörü çalışanlarının çoğunluğunu ise \%27,7 ile 26-30 yaş aralığına sahip 54 çalışan oluşturmaktadır. Her iki grupta (sektörde), çalışanların çoğunluğunu 26-30 yaş aralığına sahip çalışanlar oluşturmaktadır. 


\subsection{Veri Toplama Araçları}

Kullanılan anket formu 4 bölümden oluşmaktadır. Nepotizm ölçeği 18 ifadeden oluşmaktadır. Ford ve McLaughin (1985)'in ölçeğinden yararlanarak Abdalla vd. (1998)'nin geliştirdiği ölçeğin Türkçe versiyonuna Asunakutlu ve Avcı (2010)'dan ulaşılmıştır. Örgütsel yalnızlığı ölçmek için Wright vd. (2006)'nin geliştirdiği ölçeğe Doğan vd. (2009)'nin çalışmasından ulaşılmıştır. İşgören performansı içinse Kirkman ve Rosen (1999)'nın geliştirdiği, Sigler ve Pearson (2000)'ın kullandığı işgören performansı ölçeği Akdemir ve Çalış Duman (2016)'ın çalışmalarında kullandığı ölçekten yararlanılmıştır. Anketin son bölümünde, cinsiyet, yaş, eğitim durumu, gelir durumu, kurumdaki idari/yöneticilik görev durumu, çalıştığı kurumun niteliği, iş tecrübesi, kurumdaki çalışma süresi ve mesleği olmak üzere katılımcılara toplamda 10 adet demografik soru yöneltilmiştir.

\section{BULGULAR}

$\mathrm{Bu}$ çalışmada, hipotezlerin değerlendirilmesinde özel sektör ve kamu çalışanları arasında karşılaştırma yapabilmek için analizlerin, her iki grup için ayrı ayrı yapılmasına karar verilmiştir. Bu nedenle özel sektör ve kamu çalışanları iki ayrı örneklem olarak ele alınmış hem ölçeklere ilişkin analizler hem de hipotezlere ilişkin analizler iki grup için ayrı ayrı yapılarak raporlanmıştır. Ölçeklerin ifade sayılarının birbirinden farklı olması sebebiyle ortalama puanları alınarak analizler gerçekleştirilmiştir.

\section{1. Ölçeklere İlişkin Bulgular}

Kullanılan ölçeklerin faktör yapılarının sınanması ve yapılan analizlerin örneklem uygunluklarının test edilmesi amacı ile açımlayıcı faktör analizi yapılmıştır. Alan yazında, nepotizm ölçeğinin 3 boyutlu ve tek boyutlu olarak kullanıldığ çalışmalar bulunmaktadır. Bu çalışmada nepotizm ölçeğinin tek boyutlu versiyonu kullanılmıştır (Pelit vd., 2017). Analiz için örgütsel yalnızlık ölçeğinin de tek boyutlu versiyonu kullanılmıştır (Oğuz \& Kalkan, 2014). Örgütsel yalnızlık ölçeğinde ise hem iki boyutlu hem de tek boyutlu yapılarda 8 ifadenin düşük yüklendiği görülmüş, bu nedenle analizden çıkarılmış, tek boyut olarak değerlendirilmiştir (Tablo 2).

Tablo 2: Faktör ve Güvenilirlik Analizleri

\begin{tabular}{llcccc}
\hline & Ölçekler & Soru Sayısı & KMO & Açılklanan Varyans \% & Cronbach Alpha \\
\hline \multirow{2}{*}{$\begin{array}{l}\text { Özel Sektör } \\
\text { Çalışanları }\end{array}$} & Nepotizm & 18 &, 945 & 58,407 &, 957 \\
\cline { 2 - 6 } & Örgütsel Yalnızlık & 8 &, 898 & 59,591 &, 900 \\
\cline { 2 - 6 } Kamu & İsören Performansı & 11 &, 905 & 54,159 &, 914 \\
Çalışanları & Nepotizm & 18 &, 940 & 64,864 &, 859 \\
\cline { 2 - 6 } & Örgütsel Yalnızlık & 8 &, 887 & 59,050 &, 932 \\
\cline { 2 - 6 } $\begin{array}{l}\text { Kamu ve Özel } \\
\text { Sektör Birlikte }\end{array}$ & Nepören Performansı & 11 &, 898 & 59,871 &, 962 \\
\cline { 2 - 6 } & Örgütsel Yalnızlık & 18 &, 955 & 61,402 &, 901 \\
\cline { 2 - 6 } & İsören Performans1 & 11 &, 901 & 59,684 & 56,619 \\
\hline
\end{tabular}

Araştırmada belirlenen Kaiser-Meyer-Olkin (KMO>0,5) değerleri, ölçeklerin faktör analizi için uygun olduğu ve değişkenler arasında bir ilişki bulunduğunu göstermektedir (Kalayc1, 2010). Tablo 2'ye göre araştırmada kullanılan değişkenlerin güvenilirlik (Cronbach Alpha) değerlerinin 0,80' den yüksek olduğu görülmekte ve ölçekler yüksek derecede güvenilir kabul edilmektedir (Kalaycı, 2010). Geçerlik ve güvenirlik analizleri sonrasında normallik testleri yapılmış, histogram grafiği, basıklık ve çarpıklık değerleri kontrol edilmiş, verilerin normal ya da normale yakın dağıldıkları belirlenmiştir (Kline, 2011).

\subsection{Hipotezlere İlișkin Bulgular}

Araştırmada, hipotezlerin değerlendirilmesinde özel sektör ve kamu çalışanları arasında karşılaş̧ırma yapabilmek için analizler her iki grup için ayrı ayrı yapılmış ve raporlanmıştır.

Nepotizm, örgütsel yalnızlık ve işgören performansı arasındaki ilişkilerin belirlenmesine yönelik $\mathrm{H}_{1}$ hipotezinin test edilmesi amacıyla Pearson korelasyon analizi yapılmıştır. Pearson korelasyon analizinde "korelasyon katsayısının 0,00-0,25 aralı̆̆ında çok zayıf; 0,26-0,49 aralığında zayıf; 0,50-0,69 aralığında orta; 0,70-0,89 yüksek ve 0,90-1,00 aralığında ise çok yüksek bir ilişki olduğu şeklinde yorumlanmaktadır" (Kalayc1, 2010: 116). Tablo 3'te görüldüğü üzere, özel sektörde 
nepotizm ile örgütsel yalnızlık arasında pozitif yönlü zayıf $(\mathrm{r}=0,341)$ bir ilişki, örgütsel yalnızlık ve işgören performansı arasında ise negatif yönlü zayıf $(\mathrm{r}=-0,318)$ bir ilişki bulunmaktadır. Nepotizm ve işgören performansı arasında ise negatif yönlü çok zayıf $(\mathrm{r}=-0,140)$ bir ilişki olduğu görülmektedir. Buna göre en yüksek ilişki nepotizm ve örgütsel yalnızlık değişkenleri arasındadır. Bu sonuçlara göre " $\mathrm{H}_{1 a}$ : Özel sektör çalışanlarının nepotizm, örgütsel yalnızlık ve işgören performansı arasında anlamlı bir ilişki vardır” hipotezi desteklenmiştir.

Tablo 3: Korelasyon Analiz Değerleri (Özel Sektör Çalışanları)

\begin{tabular}{lccc}
\hline & 1. İsö̈ren Performansı & 2.Nepotizm & 3.Örgütsel Yalnızlık \\
\hline 1.İşörren Performansı & 1 & & \\
\hline 2.Nepotizm &,$- 140^{*}$ & 1 & 1 \\
\hline 3.Örgütsel Yalnızlık &,$- 318^{* *}$ &, $341^{* *}$ & \\
\hline${ }^{*} \mathrm{p}<0.05,{ }^{* *} \mathrm{p}<0.01$ & & &
\end{tabular}

Tablo 4'teki bulgulara göre, kamu çalıșanlarının nepotizm algıları ile örgütsel yalnızlık arasında pozitif yönlü zayıf $(\mathrm{r}=0,493)$ anlamlı bir ilișkinin olduğu görülmektedir. Nepotizm ve işgören performansı ile örgütsel yalnızlık ve işgören performansı arasında anlamlı bir ilişki bulunmamıştır. " $\mathrm{H}_{1 b}$ : Kamu çalışanlarının nepotizm, örgütsel yalnızlık ve işgören performansı arasında anlamlı bir ilişki vardır." hipotezi kısmen desteklenmiştir. $\mathrm{H}_{1 a}$ hipotezi desteklenirken, $\mathrm{H}_{1 \mathrm{~b}}$ hipotezi analiz bulgularına göre kısmen desteklendiği için " $\mathrm{H}_{1}$ : Nepotizm, örgütsel yalnızlık ve işgören performansı arasında anlamlı bir ilişki vardır" hipotezi kısmen desteklenmiştir.

Tablo 4: Korelasyon Analiz Değerleri (Kamu Çalışanları)

\begin{tabular}{lccc}
\hline & 1.İşgören Performansı & 2.Nepotizm & 3.Örgütsel Yalnızlık \\
\hline 1.İşgören Performansı & 1 & & \\
\hline 2.Nepotizm &, 074 & 1 & \\
\hline 3.Örgütsel Yalnızlık &,- 044 &, $493^{* *}$ & 1 \\
\hline${ }^{* * *}<0.01$ & & &
\end{tabular}

Nepotizmin örgütsel yalnızlık üzerindeki etkisini inceleyen $\mathrm{H}_{2}, \mathrm{H}_{2 \mathrm{a}}$ ve $\mathrm{H}_{2 \mathrm{~b}}$ hipotezlerinin test edilmesi için basit doğrusal regresyon analizi kullanılmıştır. Özel sektör çalışanlarının algıladıkları nepotizmin örgütsel yalnızlık üzerindeki etkisini inceleyen $\mathrm{H}_{2 \mathrm{a}}$ hipotezinin test edilmesi için yapılan basit doğrusal regresyon analizi sonuçları incelendiğinde, $\mathrm{R}^{2}$ değerinin nepotizmin örgütsel yalnızlık üzerindeki değişimin \% 11,6'sını açıkladığı görülmektedir (Tablo 5). Regresyon katsayıları $(B=0,32)$ değeri ise nepotizmdeki bir birimlik artışın örgütsel yalnızlık üzerinde 0,32 'lik artışa neden olduğu görülmektedir. Bu sonuca göre, özel sektör çalışanlarında nepotizmin örgütsel yalnızlık değişkeni üzerinde anlamlı $(\mathrm{p}<0,05)$ ve pozitif $(\mathrm{B}=0,32)$ bir etkisinin olduğu şeklinde geliştirilen " $\mathrm{H}_{2 \mathrm{a}}$ : Özel sektör çalışanlarının nepotizm algılarının örgütsel yalnızlık üzerinde anlamlı bir etkisi vardır." hipotezi desteklenmiştir.

Kamu çalışanlarının algıladıkları nepotizmin örgütsel yalnızlık üzerindeki etkisini inceleyen $\mathrm{H}_{2 \mathrm{~b}}$ hipotezinin test edilmesi için yapılan basit doğrusal regresyon analizi sonuçları incelendiğinde, $\mathrm{R}^{2}$ değerinin nepotizmin örgütsel yalnızlık üzerindeki değişimin \% 24,3'ünü açıkladığı görülmektedir (Tablo 5). Regresyon katsayıları $(\mathrm{B}=0,40)$ değeri ise nepotizmdeki bir birimlik artışın örgütsel yalnızlık üzerinde 0,40 'lık artışa neden olduğu görülmektedir. Bu sonuca göre, nepotizmin örgütsel yalnızlık değişkeni üzerinde anlamlı $(\mathrm{p}<0,05)$ ve pozitif $(\mathrm{B}=0,40)$ bir etkisinin olduğu şeklinde geliştirilen " $\mathrm{H}_{2 \mathrm{~b}}$ : Kamu çalışanlarının nepotizm algılarının örgütsel yalnızlık üzerinde anlamlı bir etkisi vardır." desteklenmiştir. $\mathrm{H}_{2 \mathrm{a}}$ ve $\mathrm{H}_{2 \mathrm{~b}}$ hipotezlerinin desteklenmesi neticesinde $\mathrm{H}_{2}$ hipotezi desteklenmiştir. Kamu ve Özel sektör çalışanları bakımından iki analiz karşılaştırıldığında nepotizmin örgütsel yalnızlık üzerindeki etkisinin kamu çalışanları üzerinde daha etkili olduğu görülmektedir. 
Tablo 5: Basit Doğrusal Regresyon Analizleri ve Hiyerarşik Regresyon Analizleri

\begin{tabular}{|c|c|c|c|c|c|c|c|c|}
\hline & & & $\begin{array}{l}\text { Özel Sek } \\
\mathrm{N}=212\end{array}$ & Çalışaı & & Kamu & anları & 195 \\
\hline \multirow{3}{*}{$\begin{array}{l}\mathrm{H}_{2} \text { Hipotezi (Basit } \\
\text { Doğrusal Regresyon } \\
\text { Analizi) }\end{array}$} & $\begin{array}{l}\text { Bağımsız } \\
\text { Değișken }\end{array}$ & $\begin{array}{l}\text { Bağımlı } \\
\text { Değişken }\end{array}$ & B & $\beta$ & $\mathbf{t}$ & B & $\beta$ & $\mathbf{t}$ \\
\hline & \multirow[b]{2}{*}{ Nepotizm } & \multirow[b]{2}{*}{$\begin{array}{l}\text { Örgütsel } \\
\text { Yalnızlık }\end{array}$} &, $328 *$ &, $341 *$ & 5,251 &, $409 *$ & ,493* & 7,878 \\
\hline & & & $\begin{array}{l}\mathrm{R}^{2}=, 116^{*} \\
{ }^{2} \\
\text { Düz. R }= \\
\mathrm{F}=27,569\end{array}$ & & & $\begin{array}{l}\mathrm{R}^{2}=, 243 \\
{ }^{2} \\
\text { Düz. R } \\
\mathrm{F}=62,05\end{array}$ & & \\
\hline \multirow{3}{*}{$\begin{array}{l}\mathrm{H}_{3} \text { Hipotezi (Basit } \\
\text { Doğrusal Regresyon } \\
\text { Analizi) }\end{array}$} & $\begin{array}{l}\text { Bağımsız } \\
\text { Değișken }\end{array}$ & $\begin{array}{l}\text { Bağımlı } \\
\text { Değișken }\end{array}$ & B & $\boldsymbol{\beta}$ & $\mathbf{t}$ & B & $\boldsymbol{\beta}$ & $\mathbf{t}$ \\
\hline & \multirow[b]{2}{*}{ Nepotizm } & \multirow[b]{2}{*}{$\begin{array}{l}\text { İşgören } \\
\text { Performans1 }\end{array}$} &,$- 093 *$ &,$- 140^{*}$ & $-2,046$ &, 049 &, 074 & 1,024 \\
\hline & & & $\begin{array}{l}\mathrm{R}^{2}=, 020^{*} \\
{ }^{2} \\
\text { Düz. }{ }^{2}= \\
\mathrm{F}=4,187\end{array}$ & & & $\begin{array}{l}\mathrm{R}^{2}=, 005 \\
{ }^{2} \\
\text { Düz. R } \\
\mathrm{F}=1,04 \mathrm{C}\end{array}$ & & \\
\hline \multirow[b]{2}{*}{$\begin{array}{l}\mathrm{H}_{4} \text { Hipotezi (Basit } \\
\text { Doğrusal Regresyon } \\
\text { Analizi) }\end{array}$} & $\begin{array}{l}\text { Bağımsız } \\
\text { Değişken }\end{array}$ & $\begin{array}{l}\text { Bağımlı } \\
\text { Değişken }\end{array}$ & B & $\boldsymbol{\beta}$ & $\mathbf{t}$ & B & $\beta$ & $\mathbf{t}$ \\
\hline & $\begin{array}{l}\text { Örgütsel } \\
\text { Yalnızlık }\end{array}$ & $\begin{array}{l}\text { İşgören } \\
\text { Performans1 }\end{array}$ & $\begin{array}{c}-, 221 * \\
{ }^{2}=, 101 * \\
2 \\
\text { Düz. R }= \\
\mathrm{F}=23,614\end{array}$ &,$- 318^{*}$ & $-4,869$ & $\begin{array}{l}-, 035 \\
{ }^{2}=, 02 \\
{ }^{2} \\
\text { Düz. R } \\
\mathrm{F}=, 378 \\
\end{array}$ &,- 044 &,- 615 \\
\hline \multirow{7}{*}{$\begin{array}{l}\mathrm{H}_{5} \text { Hipotezi } \\
\text { (Hiyerarşik } \\
\text { Regresyon Analizi) }\end{array}$} & Bağımsız & Bağımlı & & Model 1 & & & Model & \\
\hline & Değişken & Değişken & B & $\beta$ & $\mathbf{t}$ & B & $\boldsymbol{\beta}$ & $\mathbf{t}$ \\
\hline & Nepotizm & $\begin{array}{l}\text { İşgören } \\
\text { Performans1 }\end{array}$ & \multicolumn{2}{|c|}{$\begin{array}{l}\mathrm{R}^{2}=, 020^{*} \\
2 \\
\text { Düz. } \mathrm{R}^{2}=, 015 \\
\mathrm{~F}=4,187\end{array}$} & $-2,046$ & \multicolumn{2}{|c|}{$\begin{array}{l}\mathrm{R}^{2}=, 005 \\
2 \\
\text { Düz. } \mathrm{R}^{2}=, 000 \\
\mathrm{~F}=1,049\end{array}$} & 1,024 \\
\hline & Bağımsız & Bağımlı & \multicolumn{3}{|c|}{ Model 2} & \multicolumn{3}{|c|}{ Model 2} \\
\hline & Değișkenler & Değişken & B & $\beta$ & $\mathbf{t}$ & B & $\beta$ & $\mathbf{t}$ \\
\hline & Nepotizm & & $\begin{array}{c}\mathbf{- , 0 2 4} \\
-, 213^{*} \\
\end{array}$ & $\begin{array}{c}-, \mathbf{0 3 6} \\
-, 306^{*} \\
\end{array}$ & $\begin{array}{c}-, 511 \\
-4,386 \\
\end{array}$ & $\begin{array}{c}, 083 \\
-, 085 \\
\end{array}$ & $\begin{array}{r}126 \\
-, 106 \\
\end{array}$ & $\begin{array}{r}1,530 \\
-1,291 \\
\end{array}$ \\
\hline & $\begin{array}{l}\text { Örgütsel } \\
\text { Yalnızlık }\end{array}$ & $\begin{array}{l}\text { İşgören } \\
\text { Performans1 }\end{array}$ & $\begin{array}{l}\mathrm{R}^{2}=, 102 * \\
2 \\
\text { Düz. } \mathrm{R}^{2}= \\
\mathrm{F}=11,896\end{array}$ & & & $\begin{array}{l}\mathrm{R}^{2}=, 014 \\
\text { Düz. R } \\
\mathrm{F}=1,360\end{array}$ & & \\
\hline
\end{tabular}

$* \mathrm{p}<0,05$

Nepotizmin işgören performansı üzerindeki etkisini inceleyen $\mathrm{H}_{3}, \mathrm{H}_{3 \mathrm{a}}$ ve $\mathrm{H}_{3 \mathrm{~b}}$ hipotezlerinin test edilmesi için basit doğrusal regresyon analizi kullanılmıştır. Özel sektör çalışanlarının algıladıkları nepotizmin işgören performansı üzerindeki etkisini inceleyen $\mathrm{H}_{3 \mathrm{a}}$ hipotezinin test edilmesi için yapılan analiz sonuçları incelendiğinde, $\mathrm{R}^{2}$ değerine göre işgören performansı üzerindeki değişimin \% 02 'sinin nepotizmle açıklanabildiği görülmektedir (Tablo 5). B değerinden değişkenler arasında negatif $(-, 093)$ ve anlamlı $(\mathrm{p}<0,05)$ bir etkisinin olduğunu göstermektedir. Bu durum, nepotizm düzeyindeki bir birimlik artışın işgören performansı üzerinde \%09'luk bir azalışa neden olduğunu göstermektedir. Böylece " $\mathrm{H}_{3 \mathrm{a}}$ : Özel sektör çalışanlarının nepotizm algılarının işgören performansı üzerinde anlamlı bir etkisi vardır." hipotezi desteklenmiştir.

Kamu çalışanlarının algıladıkları nepotizmin işgören performansı üzerindeki etkisini inceleyen $\mathrm{H}_{3 \mathrm{~b}}$ hipotezinin test edilmesi için yapılan basit doğrusal regresyon analizi sonuçları incelendiğinde, ANOVA tablosu $(p=, 307 ; p>0,05)$ modelin anlamsız olduğunu, nepotizmin işgören performansı üzerinde anlamlı bir etkisinin olmadığını göstermektedir (Tablo 5). Bu durumda " $\mathrm{H}_{3 \mathrm{~b}}$ : Kamu açlışanlarının nepotizm algılarının işgören performansı üzerinde anlamlı bir etkisi vardır." hipotezi desteklenmemiştir. $\mathrm{H}_{3 \mathrm{a}}$ hipotezi desteklenirken, $\mathrm{H}_{3 \mathrm{~b}}$ hipotezi desteklenmediğinden " $\mathrm{H}_{3}$ : Nepotizmin işgören performansı üzerinde anlamlı bir etkisi vardır." Hipotezi kısmen desteklenmiştir.

Örgütsel yalnızlığın işgören performansı üzerindeki etkisini inceleyen $\mathrm{H}_{4}, \mathrm{H}_{4 a}$ ve $\mathrm{H}_{4 b}$ hipotezlerinin test edilmesi için basit doğrusal regresyon analizi kullanılmıştır. $\mathrm{H}_{4 \mathrm{a}}$ hipotezinin test 
edilmesi için yapılan basit doğrusal regresyon analizi sonuçları incelendiğinde, $\mathrm{R}^{2}$ değerine göre işgören performansı üzerindeki değişimin \%10’u örgütsel yalnızlık değişkeniyle açılanabildiği görülmektedir (Tablo 5). Regresyon katsayısının $(\mathrm{B}=-, 221)$ negatif olması ise, örgütsel yalnızlığın işgören performansını negatif yönde etkilediğini göstermektedir. Örgütsel yalnızlıktaki bir birimlik artış, işgören performansında \%22'lik bir azalışa neden olmaktadır. Buna göre " $\mathrm{H}_{4 a}$ : Özel sektör çalışanlarının örgütsel yalnızlık algılarının işgören performansı üzerinde anlamlı bir etkisi vardır." hipotezi desteklenmiştir.

Kamu çalışanlarının algıladıkları örgütsel yalnızlığın işgören performansı üzerindeki etkisini inceleyen $\mathrm{H}_{4 b}$ hipotezinin test edilmesi için yapılan basit doğrusal regresyon analizi sonuçları incelendiğinde, ANOVA tablosu $(p=, 539 ; p>0,05)$ modelin anlamsız olduğunu, örgütsel yalnızlı̆̆n işgören performansı üzerinde anlamlı bir etkisinin olmadığını göstermektedir (Tablo 5). Buna göre " $\mathrm{H}_{4 \mathrm{~b}}$ : Kamu çalışanlarının örgütsel yalnızlık algılarının işgören performansı üzerinde anlamlı bir etkisi vardır." hipotezi desteklenmemiştir. $\mathrm{H}_{4 \mathrm{a}}$ hipotezi desteklenirken, $\mathrm{H}_{4 \mathrm{~b}}$ hipotezi desteklenmediğinden " $\mathrm{H}_{4}$ : Örgütsel yalnızlı̆̆ın işgören performansı üzerinde anlamlı bir etkisi vardır." hipotezi kısmen desteklenmiştir.

Nepotizmin işgören performansı üzerindeki etkisinde örgütsel yalnızlığın aracı rolüne ilişkin $\mathrm{H}_{5}, \mathrm{H}_{5 \mathrm{a}}$ ve $\mathrm{H}_{5 \mathrm{~b}}$ hipotezleri geliştirilmiştir. Örgütsel yalnızlığın aracılık etkisinin belirlenmesinde Baron ve Kenny (1986), tarafından önerilen "aracı değişken analizi yöntemi” kullanılmıştır. Bu yönteme göre bağımlı değişken (işgören performansı) üzerinde bağımsız (nepotizm) ve aracı değiş̧kenin (örgütsel yalnızlık) ayrı ayrı direkt etkisi (y ve z) olmalı, ayrıca bağımsız değişken ile aracı değişken arasında ilişki (x) olmalıdır (Akt., Demir, 2010). Bu yönteme göre son şart ise aracı değişken ve bağımsız değişkenin analize birlikte dâhil edildiğinde bağımsız değişkenin bağımlı değişken üzerindeki etkisinin azalması veya etkisini tamamen kaybetmesidir. Bağımsız değişkeninin etkisinin azaldığı veya kaybolduğu durumda aracılık rolünün varlığg kabul edilmektedir (Akt., Büte, 2011b). Bu bağlamda araştırmada, $\mathrm{H}_{2}(\mathrm{x})$ nepotizmin örgütsel yalnızlık üzerindeki etkisinin, $\mathrm{H}_{3}(\mathrm{z})$ nepotizmin işgören performansı üzerindeki etkisinin, $\mathrm{H}_{4}(\mathrm{y})$ ise örgütsel yalnızlı̆̆ın işgören performansı üzerindeki etkisini özel sektör ve kamu çalışanları bazında iki ayrı örneklem üzerinden regresyon analizine tabi tutulmuştur.

Yapılmış olan basit doğrusal regresyon analizleri sonucunda nepotizm ve örgütsel yalnızlığın (aracı değişken) işgören performansı üzerinde direkt etkisi olduğu ortaya çıkmıştır. Şekil 2'deki etkiler özel sektör çalışanları için $\mathrm{H}_{2 \mathrm{a}}(\mathrm{x}), \mathrm{H}_{3 \mathrm{a}}(\mathrm{z})$ ve $\mathrm{H}_{4 \mathrm{a}}(\mathrm{y})$ hipotezlerinin test edilmesinde kullanılan basit doğrusal regresyon analizi sonuçları ile doğrulanmıştır. Baron ve Kenny (1986)'nin ifade ettiği aracı değişken analiz şartlarından ilk ikisi gerçekleşmiş olup, üçüncü şartın da test edilmesi amacıyla, nepotizm ve örgütsel yalnızlığın bağımsız değişkenler olarak birlikte analize dâhil edildiği hiyerarşik regresyon analizi yapılmıştır. Sonuçlar Tablo 12'de yer almaktadır. Tablo 5'de göründügü üzere Model 1'de nepotizmin işgören performansı üzerinde düşükte olsa negatif yönlü anlamlı bir etkiye sahip olduğu $(B=-, 093)$, işgören performansının \%1,5'ini açıkladığı görülmektedir. Model 2'de nepotizm ile birlikte örgütsel yalnızlık değişkeni de dâhil edilmiş; yeni modelin işgören performansını açıklama oranı \%9,4'yükselmiş olmakla birlikte, nepotizmin işgören performansı üzerindeki etkisi (B=-,093; Beta=-,140) iken, Model 2'de örgütsel yalnızlık ile birlikte analize dâhil edildiğinde, nepotizmin etkisinin anlamsız olduğu $(p=610 ; p>0,05)$ belirlenmiştir. Bu durumda örgütsel yalnızlığın, nepotizm ile işgören performansı arasında aracı değişken rolü üstlendiği söylenebilir. Nepotizm ve işgören performansı arasındaki anlamlı ilişki, analize örgütsel yalnızlık dâhil edildiğinde anlamını kaybetmektedir ( $\mathrm{p}=, 610 ; \mathrm{p}<0,05)$. Baron ve Kenny (1986)'nin aracı değişkeni test etmek için gerekli üçüncü şartının sağlanarak, nepotizmin işgören performansı ile ilişkisinde örgütsel yalnızlığın "tam aracı değişken" rolü olduğunu göstermektedir.

Örgütsel yalnızlığın aracılık etkisinin anlamlılığını doğrulamak amacıyla Sobel Testi yapılmış ve aracılık etkisi teyit edilmiştir ( $\mathrm{p}<0,05)$. Test sonuçları Tablo 6' da gösterilmiştir. Bunun sonucunda " $\mathrm{H}_{5 \mathrm{a}}$ : Özel sektör çalışanlarının algıladıkları nepotizmin işgören performansı üzerindeki etkisinde örgütsel yalnızlığın aracılık rolü vardır.” hipotezi desteklenmektedir. 
Tablo 6: Nepotizmin İşgören Performansı Üzerindeki Etkisinde Örgütsel Yalnızlığın Aracılık Rolü (Sobel Testi)

\begin{tabular}{llllll}
\hline Girdi & & Test & Test İstatistikleri & Std. Sapma & p-değeri \\
\hline a & 0,328 & Sobel & 5,11800313 & 0,05960137 & 0,00000031 \\
\hline b & 0,93 & Aroian & 5,11215372 & 0,05966957 & 0,00000032 \\
\hline Sa & 0,062 & Goodman & 5,12387267 & 0,0595331 & 0,0000003 \\
\hline Sb & 0,046 & & & & \\
\hline
\end{tabular}

Kaynak: http://quantpsy.org/sobel/sobel.htm

Kamu çalışanlarının algıladıkları nepotizmin işgören performansı üzerindeki etkisinde örgütsel yalnızlığın aracılık rolünü inceleyen $\mathrm{H}_{5 b}$ hipotezinin test edilmesi amacıyla Baron ve Kenny (1986)'nin önermiş olduğu, aracı değişken analizi yöntemi kullanılmıştır. Yapılmış olan basit doğrusal regresyon analizleri sonucunda kamu çalışanlarının algıladıkları nepotizmin işgören performansı üzerinde anlamlı direkt etkisi olmadığı, ortaya konmuştur. Etkiler $\mathrm{H}_{2 \mathrm{~b}}(\mathrm{x}), \mathrm{H}_{3 \mathrm{a}}(\mathrm{z})$ ve $\mathrm{H}_{4 \mathrm{a}}(\mathrm{y})$ hipotezlerinin test edilmesinde kullanılan basit doğrusal regresyon analizi sonuçları ile kamu çalışanları için değerlendirildiğinde sadece $\mathrm{H}_{2 \mathrm{~b}}(\mathrm{x})$ "Kamu çalışanlarının nepotizm algılarının örgütsel yalnızlık üzerinde anlamlı bir etkisi vardır." Doğrulanmış, diğer etkileri ise doğrulanmamıştır. Baron ve Kenny (1986)'nin ifade ettiği aracı değişken analiz şartlarından ilki gerçekleşmişse de ikinci ve üçüncü şart sağlanmadığı için aracılık etkisi söz konusu değildir. Nitekim yapılan hiyerarşik regresyon analizi sonucunda (Tablo 5) hem Model 1 hem de Model 2 ANOVA tablosu değerleri istatistiki olarak anlamsız çıkmıştır. Dolayısıyla " $\mathrm{H}_{5 \mathrm{~b}}$ : Kamu çalışanlarının algıladıkları nepotizmin işgören performansı üzerindeki etkisinde örgütsel yalnızlı̆̆ın aracılık rolü vardır." hipotezi desteklenmemiştir.

\section{SONUÇ}

Nepotizm kavramı, özünde birilerine ayrıcalıklı davranırken kan bağını esas alan kayırmacılık türüdür (Pelit vd., 2017). Bu araştırmanın amacı, çalışanların iş ortamında algıladıkları nepotizmin örgütsel yalnızlık ve işgören performansı üzerindeki etkilerinin yanısıra örgütsel yalnızlığın nepotizm ile iş gören performansı arasındaki rolünün belirlenmesidir. Araştırma kapsamında, nepotizm uygulamalarının çalışanlarda yalnızlık ve performans üzerindeki etkisi araştıılmış, nepotizm ve işgören performansı arasındaki ilişkide örgütsel yalnızlığın aracı rolü de test edilmiştir. Araştırma kapsamında Hatay ili genelinde 212 özel sektör ve 195 kamu çalışanı olmak üzere toplamda 407 katılımcıdan anket tekniği kullanılarak veri toplanmıştır. Özel sektör ve kamu çalışanları iki farklı örneklem olarak değerlendirilmiş, hipotezler her iki örneklemde de ayrı ayrı test edilmiştir.

$\mathrm{Bu}$ çalışmanın en önemli sonuçlarından biri, nepotizm ile örgütsel yalnızlık arasındaki ilişskinin incelenmiş olmasıdır. Korelasyon analizi sonucunda, hem özel sektör hem de kamu çalışanlarının algılanan nepotizm ile örgütsel yalnızlık algıları arasında pozitif yönlü anlamlı bir ilişki bulunmuştur. Yani örgütte nepotist uygulamalar arttı̆̆ında çalışanların hissettikleri yalnızlık duygusu da artmaktadır. Özel sektör çalışanlarında algılanan örgütsel yalnızlık ve işgören performansı arasında negatif yönlü anlamlı bir ilişki bulunurken; kamu çalışanlarında iki değişken arasında anlamlı bir ilişki bulunmamaktadır. Yani özel sektörde, örgütteki çalışanların yalnızlık algılarının artması, performanslarının düşmesine yol açmaktadır. Özçelik ve Barsade (2011) ile Lam ve Lau (2012) kamu ve özel sektör çalışanlarından oluşan örneklem üzerinde çalıştıkları araştırmalarında işyerindeki yalnızlık ile çalışan performansı arasında negatif yönlü anlamlı bir ilişki tespit etmişlerdir. Son olarak, nepotizm ile işgören performansı arasındaki ilişki incelendiğinde, özel sektör ve kamu çalışanları arasında ilişkinin anlamlılığ bakımından farklılık görülmektedir. Özel sektör çalışanlarında nepotizm ile işgören performansı arasında negatif yönlü anlamlı bir ilişki belirlenirken, kamu sektöründe ise nepotizm ile işgören performansı arasında anlamlı bir ilişki bulunmamaktadır. Özel sektörde nepotizm ve diğer değişkenler arasındaki ilişkiler karşılaştırıldığında, en güçlü ilişsinin örgütsel yalnızlık değişkeni ile olduğu görülmektedir. Alan yazın incelendiğinde Kaba ve Aktaş (2018) özel eğitim kurumlarında, İşlek (2019) ise yapı market sektöründeki aile işletmelerinde yapmış oldukları araştırmada, nepotizm ve bireysel performans arasında negatif yönlü anlamlı bir ilişkinin olduğu sonucuna ulaşmışlardır. Ancak, Burucuoğlu vd. (2015) ise Merzifon Organize Sanayi Bölgesindeki aile işletmelerinin çalışanlarına yönelik yapmış oldukları çalışmalarında, nepotizm ile işgören performansı arasında anlamlı bir ilişki tespit edememişlerdir. 
Araştırmada çalışanların nepotizm algılarının örgütsel yalnızlık algıları üzerindeki etkisinin test edilmesi için özel sektör ve kamu çalışanları örneklemleri için ayrı ayrı basit doğrusal regresyon analizi yapılmıştır. Analizler sonucunda, her iki örneklemde de pozitif yönlü anlamlı bir etki olduğu tespit edilmiştir. Çalışanların nepotizm algılarının işgören performansı üzerindeki etkisinin test edilmesi için her iki örneklemde ayrı olarak basit doğrusal regresyon analizi yapılmıştır. Analizler sonucunda özel sektör çalışanlarının nepotizm algılarının işgören performansları üzerinde negatif yönlü anlamlı bir etkisinin olduğu, kamu çalışanlarında ise anlamlı bir etkisinin olmadığı belirlenmiştir. Burucuoğlu vd. (2015) ise özel sektör çalışanlarına yönelik çalışmalarında algılanan nepotizmin işgören performansı üzerinde anlamlı bir etki tespit edememişlerdir. Hem nepotizm algılarının hem de örgütsel yalnızlık algılarının kamu çalışanlarının performansı üzerinde etkisinin olmamasının nedeni kamu kurumlarında, özel sektörde olduğu gibi bir performans değerleme sisteminin bulunmaması olabilir. Nitekim kamu çalışanlarının özel sektör çalışanlarına kıyasla ücret düzeylerinin ve çalışma şartlarının performansa bağlı olmaması (Barbaros, 2015), kamu çalışanlarında performans algısının özel sektör çalışanlarına göre daha düşük olmasına neden olabilir. Performans kaygısının bulunmaması, kamu çalışanlarında performans algısı üzerinde nepotizmin etkisinin olmamasina neden olabilir.

$\mathrm{Bu}$ çalışmanın bir diğer önemli yanı ise nepotizmin, işgören performansına etkisinde örgütsel yalnızlığın aracılık etkisinin tespit edilmiş olmasıdır. Örgütsel yalnızlığın aracılık etkisine özel sektör ve kamu çalışanları örneklemlerinde hiyerarşik regresyon analizi ile ayrı ayrı test edilmiştir. Özel sektör çalışanlarında örgütsel yalnızlığın algılanan nepotizm ve işgören performansı arasında tam aracılık etkisine sahip olduğu görülmüştür. Örgütsel yalnızlığın aracıllk etkisinin anlamlılığını doğrulamak amacıyla Sobel testi yapılmış, testin sonucunda ise aracılık etkisi teyit edilmiştir. Örgütsel yalnızlığın aracı role sahip olması, nepotizmin işgören performansını, işgören performansının da örgütsel yalnızlı̆̆ı etkilediği anlamına gelmektedir. Kamu çalışanlarının hem nepotizm algısının işgören performansı üzerinde anlamlı bir etkisi olmaması hem de örgütsel yalnızlığın işgören performansı üzerinde anlamlı bir etkisi olmaması sebebiyle aracılık rolünün iki temel şartını sağlamamaktadır. Dolayısıyla Kamu çalışanlarının nepotizm algıları ile işgören performansı arasında örgütsel yalnızlığın aracılık etkisi bulunmamaktadır. Bu çalışmanın en önemli sonuçlarından biri, nepotizm ile örgütsel yalnızlık arasında ilişkinin ve nepotizm algısının örgütsel yalnızlık üzerindeki etkisinin belirlenmesinin yanısıra özel sektör çalışanlarında örgütsel yalnızlığın nepotizm algısı ile işgören performansı arasındaki ilişkide aracılık rolünün ortaya konulmasıdır.

Örgütler, çalışanları işe alma, değerlendirme ve teşvik etme konusunda en iyi uygulamalardan faydalanabilirlerse, nepotizmi örgüte ve çalışanlara zarar vermeden hatta yararlı hale getirmeleri söz konusu olabilir (Bellow, 2003). Örneğin, bir pozisyon için bütün adaylar ile akraba ilişkisi olan aday benzer özelliklerde ise akrabanın seçimi kimseye zarar vermeyebilir. Böyle bir seçim çalışanlar arasında bir kutuplaşmaya neden olmayacaktır. Bu çalışmanın bulgularından biri olan örgütsel yalnızlığın aracılık etkisi göz önünde bulundurulduğunda, örgütte çalışanlar arası sosyal ilişkileri geliştirmek adına, sosyal etkinliklerin düzenlenmesi, iletişim becerilerini geliştirici eğitimlerin verilmesi (Uçkun \& Üzüm, 2019), destekleyici bir kültür yapısının oluşturulması çalışanlarda örgütsel yalnızlık algısının düşmesine, dolaylı olarak da işgörenlerin performanslarına pozitif olarak yansımasına neden olabilir. Bu çalışma, zaman ve maliyet kısıtları nedeniyle Hatay ilindeki katılımcılarla gerçekleştirilmiştir. Veri toplama sürecinin Covid-19 Pandemisine denk gelmiş olması da örnekleme ulaşmak adına bir kısıt oluşturmuştur. İleride yapılacak olan çalışmalarda örneklem sayısının arttırılması ve uzun dönemli araştırmaların, sonuçların genellenebilmesi için faydalı olacağı düşünülmektedir. Ayrıca bu çalışmada nepotizm ve örgütsel yalnızlık ölçeklerinin tek boyutlu yapıları kullanılmıştır. Ölçeklerin çok boyutlu yapılarının kullanılması daha detaylı bilgilere ulaşmayı sağlayabilecektir. Nepotizm ve örgütsel yalnızlık ile birlikte ilişkili olabilecek (işten ayrılma niyeti, iş tatmini, örgütsel yabancılaşma, örgütsel adalet, örgütsel güven gibi) değişkenler kullanılarak incelenmesinin kavramın anlaşılmasına katkı sağlayacağı düşünülmektedir. 
Etik Beyan: Bu çalışmada kullanılan anket yöntemi için Osmaniye Korkut Ata Üniversitesi Bilimsel Araştırma ve Yayın Etiği Kurulu'ndan 09/03/2020 tarihli ve 2020/10 nolu toplantısinda 2020/10/1 sayll kararl (Evrak Tarih ve Saylsi: 09/03/2020-7322) ile izin alınmıştır. Aksi bir durumun tespiti halinde AKAD Dergisinin hiçbir sorumluluğu olmayıp, tüm sorumluluk çalışmanın yazar (lar) ına aittir.

Yazar Katkı Beyant:1. Yazarın katkı oranı \%50, 2. Yazarın katkı oranı ise \%50'dir. Çıkar Beyanı: Yazarlar arasında çıkar çatışması yoktur.

Ethics Statement: Permission for this study was obtained from the Scientific Research and Publication Ethics Committee of Osmaniye Korkut Ata University with the decision number 2020/10/1at the meeting dated 09/03/2020 and numbered 2020/10 of the relevant board. In case of detection of a contrary situation, AKAD Journal has no responsibility and all responsibility belongs to the author (s) of the study.

Author Contributions Statement: 1st author's contribution rate 50\%, 2nd author's contribution rate $50 \%$.

Conflict of Interest: There is no conflict of interest among the authors.

\section{KAYNAKÇA}

Abdalla, H. F., Maghrabi, A. S., \& Raggad, B. G. (1998). Assessing the perceptions of human resource managers toward nepotism: A cross-cultural study. International Journal of Manpower, 19(8), 554-570. http://dx.doi.org/10.1108/01437729810242235

Akdemir, B., \& Çalış Duman, M. (2016). Duygusal bağlılık ve işgören performası arasındaki ilişkiye yönelik bir araştırma. The Journal of Academic Social Science Studies, 5(46). 343-357. http://dx.doi.org/10.9761/JASSS3454

Arasl1, H., \& Tümer, M. (2008). Nepotism, favoritism and cronyism: A study of their effects on job stress and job satisfaction in the banking industry of North Cyprus. Social Behavior and Personality, 36(9), 1237-1250. https://doi.org/10.2224/sbp.2008.36.9.1237

Asunakutlu, T., \& Avcı, U. (2010). Aile işletmelerinde nepotizm algısı ve iş tatmini ilişkisi üzerine bir araştırma, Süleyman Demirel Üniversitesi İktisadi ve İdari Bilimler Fakültesi Dergisi, (2), 9497. https://dergipark.org.tr/tr/pub/sduiibfd/issue/20827/223022

Avcı, A. (2017). Şirketlerde nepotizm uygulamasının çalışanların iş tatmini ve tükenmişlik düzeylerine etkisi [Yüksek lisans tezi, İstanbul Sebahattin Zaim Üniversitesi] Yüksek Öğretim Kurumu Tez Merkezi. https://tez.yok.gov.tr/UlusalTezMerkezi/tezSorguSonucYeni.jsp

Bakioğlu, A., \& Korumaz, M. (2014). Öğretmenlerin okulda yalnızlıklarının kariyer evrelerine göre incelenmesi. Eğitim Bilimleri Dergisi, 39, 28-29. http://dx.doi.org/10.15285/EBD.2014397395

Barbaros, Z. (2015). Nepotizm üzerine bir çalışma kamu özel sektör karşılaştırması [Yüksek lisans tezi, Beykent Üniversitesi] Yüksek Öğretim Kurumu Tez Merkezi. https://tez.yok.gov.tr/UlusalTezMerkezi/TezGoster?key=WY5CM7tPNE2z_YM6pBu0t0aMfS BSyWasjuWzfxkSAwSBWUhW2Q1TKoT7pmllytzH

Baron, R. M., \& Kenny, D. A. (1986). The moderator-mediator variable distinction in social psychological research: Conceptual, strategic, and statistical considerations. Journal of Personality and Social Psychology, 51(6), 1173-1182. https://doi.org/10.1037/0022$\underline{3514.51 .6 .1173}$

Bayhan, V. (2002). Demokrasi ve sivil toplum örgütlerinin engelleri: Patronaj ve nepotizm. C. $\ddot{U}$. Sosyal Bilimler Dergisi, 26(1), 1-13. http://eskidergi.cumhuriyet.edu.tr/makale/57.pdf

Bellow, A. (2003). In praise of nepotism: A natural history. Doubleday Publishing.

Burucuoğlu, M., Çapkulaç, O., \& Gül, H. H. (2015). Aile işletmelerinde nepotizmin örgütsel adalet ve iş performansı üzerindeki etkileri üzerine bir araştırma. Uluslararası Hakemli Psikiyatri ve Psikoloji Araştırmaları Dergisi (UHPPD), 2(3), https://doi.org/10.17360/UHPPD.2015310995

Büte, M. (2011a). Kayırmacılığın çalışanlar üzerine etkileri ile insan kaynakları uygulamaları ilişkisi: 
Türk kamu bankalarına yönelik bir araştırma. Atatürk Üniversitesi Sosyal Bilimler Enstitüsü Dergisi, 15(1), 383-404. https://dergipark.org.tr/en/pub/ataunisosbil/issue/2827/38309

Büte, M. (2011b). Nepotizm ve iş tatmini ilişkisinde iş stresinin aracı rolü var mıdır?. Dumlupınar $\begin{array}{lllll}\text { Üniversitesi Sosyal Bilimler } & \text { Dergisi, } & 29, & 176 .\end{array}$ https://dergipark.org.tr/tr/pub/dpusbe/issue/4771/65661

Çalık, A., \& Naktiyok, A. (2018). Nepotizmin örgütsel sessizliğe etkisinde öz yeterlilik algısının rolü: Hastane çalışanları üzerine bir araştırma. Ege Academic Review, 18(3), 343-351. https://dergipark.org.tr/en/pub/eab/issue/41358/499915

Çetinkaya, A. Ş., \& Sanioğlu Tanış, Z. (2017). Örgütlerde kayırmacılığın iş yükü algısına etkisi: Konya kamu kurumları araştırması. UïIID-IJEAS, 16. UíK Özel Sayıs1, 607-618. https://doi.org/10.18092/ulikidince.324231

Dalkıran, B. (2018). Örgütlerde nepotizm ile intikamcı davranış arasındaki ilişsiye yönelik bir araştırma [Yüksek lisans tezi, Marmara Üniversitesi] Yüksek Öğretim Kurumu Tez Merkezi. https://tez.yok.gov.tr/UlusalTezMerkezi/TezGoster?key=vbVkXe1KChYWNElr1MuLZjCf6u7 T_4T86Df9acYzF8OMugAZBw7Y649boqoqVvMa

Demir, H. (2010). Kültürel renk körlüğü: Kültürel değerler ve iş tatmini arasındaki ilişki üzerine güçlendirmenin aracılık (mediation) etkisi. Atatürk Üniversitesi İktisadi ve İdari Bilimler Dergisi, 22(2), 211-237. https://dergipark.org.tr/tr/pub/atauniiibd/issue/2694/35470

Demirbaş, B., \& Haşit, G. (2016). İş yerinde yalnızlık ve işten ayrılma niyetine etkisi: Akademisyenler üzerine bir uygulama. Anadolu Üniversitesi Sosyal Bilimler Dergisi, 1, 138141. https://dergipark.org.tr/tr/pub/ausbd/issue/26453/278546

Doğan, T., Çetin, B., \& Sungur, M. Z. (2009). İş yaşamında yalnızlık ölçeği Türkçe formunun geçerlilik ve güvenilirlik çalışması. Anadolu Psikiyatri Dergisi, 10, 272. https://toad.halileksi.net/sites/default/files/pdf/is-yasaminda-yalnizlik-olcegi-toad.pdf

Firfiray, S., Cruz, C., Neacsu, I., \& Gomez-Mejia, L. R. (2018). Is nepotism so bad for family firms? A socioemotional wealth approach. Human Resource Management Review, 28(1), 83-97. https://doi.org/10.1016/j.hrmr.2017.05.008

İşlek, S. (2019). Aile işletmelerinde nepotizmin işgören performansı üzerindeki etkisi: Trakya bölgesinde bir araştırma [Yüksek lisans tezi, Beykent Üniversitesi] Yüksek Öğretim Kurumu Tez Merkezi. https://tez.yok.gov.tr/UlusalTezMerkezi/TezGoster?key=FgmkGchPKo23q QqBeqzVZpuR7 L1XXjWlkDqxGi7K8Wc6D7U8J398XT0mI65oa d

İyiişleroğlu, S. C. (2006). Aile şirketleri: Adana ve çevresinde faaliyet gösteren aile şirketlerinde nepotizm uygulamasının tespitine yönelik bir araştırma [Yüksek lisans tezi, Çukurova $\begin{array}{lllll}\text { Üniversitesi] Ö̈̆retim } & \text { Yüksek } & \text { Kurumu } & \text { Tez } & \text { Merkezi. }\end{array}$ https://tez.yok.gov.tr/UlusalTezMerkezi/TezGoster?key=L8ilcwn9ZRRc_YMKxXW1m82Ss5TQqlhK-dmHAF4n4eXb5EGIMWSycP6ecgwEjN7

Kaba, A., \& Aktaş, H. (2018). Nepotizm ve örgütsel adalet algısının bireysel performansa etkisi: Özel eğitim kurumlarında çalışanlar üzerinde bir araştırma. Ulusal Yönetim ve Organizasyon Kongresi Bildiriler Kitab1, 26, 292-296. https://docs.google.com/file/d/1oU5HQhHnLHK44LjvaanvrzYN7umF2hL/view

Kalaycı, Ş. (2010). SPSS uygulamalı çok değiş̧kenli istatistik teknikleri (5.Baskı). Dinamik Akademi Yayınları.

Karacaoğlu, K., \& Yörük, D. (2012). Çalışanların nepotizm ve örgütsel adalet algılamaları: Orta Anadolu Bölgesinde bir aile işletmesi uygulaması, "Işs, Güç" Endüstri Illişkileri ve İnsan Kaynaklart Dergisi, 3, 46-47. https://doi.org/10.4026/1303-2860.2012.0205.x

Kayaalp, E. (2019). Öğretmenlerin örgütsel sessizlik, örgütsel yalnızlı ve örgütsel yabancllaşma algılarının örgütsel sinizm düzeyleriyle ilişkisi [Yüksek lisans tezi, Fırat Üniversitesi] Yüksek Öğretim Kurumu Tez 
https://tez.yok.gov.tr/UlusalTezMerkezi/TezGoster?key=Mir2lXQK1dkmQ9Ige3PZbqe_JI231Z bcKK2ZmZWp-EHxwuuaSrJen4J1NgCRCU_0

Kirkman, B. L., \& Rosen, B. (1999). Beyond self-management: Antecedents and consequences of team empowerment. Academy of Management Journal, (42), 58-74. https://doi.org/10.2307/256874

Lam, L. W., \& Lau, D. C. (2012). Feeling lonely at work: Investigating the consequences of unsatisfactory workplace relationships. The International Journal of Human Resource Management, 23(20), 4265-4282. https://doi.org/10.1080/09585192.2012.665070

Oğuz, E., \& Kalkan, M. (2014). Öğretmenlerin iş yaşamında algıladıkları yalnızlık ile sosyal destek düzeyleri arasındaki ilişki. Elementary Education Online, 13(3), 787-795. http://ilkogretimonline.org.tr/index.php/io/article/view/2139

Özçelik, H., \& Barsade, S. (2011). Work loneliness and employee performance. Academy of Management Proceedings, 1, 1-6. https://doi.org/10.5465/ambpp.2011.65869714

Özkanan, A., \& Erdem, R. (2014). Yönetimde kayırmacı uygulamalar: Kavramsal bir çerçeve, Süleyman Demirel Üniversitesi Sosyal Bilimler Enstitüsü Dergisi, 2, 179-206. https://dergipark.org.tr/tr/pub/sbe/issue/23217/247942

Pelit, E., Baytok, A., Soybalı, H. H., \& Kılıç, İ. (2017). Nepotizm algısında demografik özelliklerin rolü: Otel işletmeleri işgörenleri üzerinde bir araştırma. Türk Turizm Araştırma Dergisi, 2, 45 63. https://dx.doi.org/10.26677/tutad.2017.8

Polat, G. (2012). Örgütlerde nepotizmin örgütsel adalet alglsı ile ilişkisinin tespitine yönelik bir araştırma [Yüksek lisans tezi, Dumlupınar Üniversitesi] Yüksek Öğretim Kurumu Tez Merkezi. https://tez.yok.gov.tr/UlusalTezMerkezi/TezGoster?key=RYan9_SZ7Eir3xdWGXBiLnSMaXtZgvIRAYqSn8RqLTVX-9B5BQCIjbaAqOAQWh8

Riggio, R. E., \& Saggi, K. (2015). If we do our job correctly, nobody gets hurt by nepotism. Industrial and Organizational Psychology, 8(1), 19-20. https://doi.org/10.1017/iop.2014.5.

Savaş, Y. (2015). Nepotizmin yenilik ve yetenek yönetimi üzerine etkisi [Yüksek lisans tezi, Aksaray Üniversitesi] Yüksek Öğretim Kurumu Tez Merkezi. https://tez.yok.gov.tr/UlusalTezMerkezi/TezGoster?key=WBc656i315e2eV6EZV1om_YQVPNc10BA31ksTRqUNJRp0ZWOjM218M1syDUoFQ0

Sigler, T. H., \& Pearson, C. M. (2000). Creating an empowering culture: Examining the relationship between organizational culture and perceptions of empowerment. Journal of Quality Management, 5, 27-52. https://doi.org/10.1016/S1084-8568(00)00011-0

Uçkun, S., \& Üzüm, B. (2019). Örgütsel yalnızlığa bir bakış. Social Mentality and Researcher Thinkers Journal, 5(15), 125-130. https://doi.org/10.31576/smryj.192

Üstük, İ. (2018). Cinsiyet ayrımcılığının ve cinsiyete dayalı nepotizmin çalışan performansı üzerindeki etkisi [Yüksek lisans tezi, Beykent Üniversitesi] Yüksek Öğretim Kurumu Tez Merkezi. https://tez.yok.gov.tr/UlusalTezMerkezi/TezGoster?key=fS4sqEZr79C n60Rk6MjFW2FPXhnu SNIcJU4WhAjFksxcyCVmJFFqIiwW_XTYR7I

Vateva, N. (2009). The impact of favoritism on work motivation case study [Master Thesis, University of Maastricht]

Wright, S. L., Burt, C. D. B., \& Strongman K. T. (2006). Loneliness in the workplace: Construct definition and scale development. NZ $J$ Psychology, 35(2), 59-68. https://ir.canterbury.ac.nz/bitstream/handle/10092/2751/12602927 Loneliness\%20in\%20the\%2 0Workplace\%20-Scale\%20Developlment.pdf?sequence=1\&isAllowed=y 